\title{
Isolation of antioxidant components from Corni fructus
}

\author{
Su-Hui Kim ${ }^{1}$, Gi-Un Seong ${ }^{1}$, Shin-Kyo Chung ${ }^{1,2 *}$ \\ ${ }^{1}$ School of Food Science and Biotechnology, Kyungpook National University, Daegu 41566, Korea \\ ${ }^{2}$ Food and Bio-Industry Research Institute, Kyungpook National University, Daegu 41566, Korea
}

\section{산수유(Corni fructus)에서 분리한 항산화 생리활성물질의 특성}

\author{
김수희 ${ }^{1} \cdot$ 성기운 $^{1} \cdot$ 정신교 ${ }^{1,2 *}$ \\ '경북대학교 식품공학부, ${ }^{2}$ 경북대학교 식품생물산업연구소
}

\begin{abstract}
A 90\% ethanol extract of Corni fructus was fractioned and the active components (i.e., morroniside, loganin) were isolated for functional food materialization. More specifically, the ethanol extract was fractioned according to the solvent polarity (i.e., $n$-hexane, ethyl acetate, and $n$-butanol), and the ethyl acetate fraction was found to exhibiti the highest antioxidant capacities (i.e., total phenolic content $=145.84 \mathrm{GAE} \mathrm{mg} / 100 \mathrm{~mL}$, DPPH radical scavenging activity $=7.91 \mathrm{mM}$ GAE, FRAP activity $=18.86 \mathrm{mM}$ TE, ABTS radical scavenging activity $=13.36 \mathrm{mM} \mathrm{TE}$ ). Diaion HP 20 gel was used for separation of the ethyl acetate fraction, and $20 \%, 40 \%, 60 \%$, and $80 \%$ ethanol fractions were also examined. The $40 \%$ ethanol fraction was found to exhibit the highest DPPH radical scavenging activity (10.22 mM GAE), ABTS radical scavenging activity (37.29 mM TE), and FRAP activity (27.32 mM TE) $(p<0.05)$. The total phenolic compound content $(580.84 \mathrm{GAE} \mathrm{mg} / 100 \mathrm{~mL})$, total flavonoid content $(166.24 \mathrm{CE}$ $\mathrm{mg} / 100 \mathrm{~mL})$, and total anthocyanin content $(0.74 \mathrm{mg} / 100 \mathrm{~mL})$ followed a similar trend, again being the highest for this fraction. Two components (i.e., morriniside, loganin) were identified in the ethyl acetate and $40 \%$ ethanol fractions, and their contents were determined by high-performance liquid chromatography. Furthermore, the $40 \%$ ethanol fraction contained the highest quantity of total active components $(\mathbf{p}<\mathbf{0 . 0 5})$, and the presence of momoniside (405 $[\mathrm{M}-\mathrm{H}]^{-}$and $\left.451[\mathrm{M}+\mathrm{COOH}-\mathrm{H}]^{-}\right)$and loganin $\left(389[\mathrm{M}-\mathrm{H}]^{-}\right.$and $\left.435[\mathrm{M}+\mathrm{COOH}-\mathrm{H}]^{-}\right)$were confirmed by ultra-performance liquid chromatography-mass spectrometry.
\end{abstract}

Key words : Corni fructus, antioxidant capacity, morroniside, loganin, UPLC-MS

서 론

예전에는 질병의 치료나 예방을 위해 화학제품을 이용 하여 여러 기능성 식품을 개발하여 사용해왔으나, 최근 바이오산업의 급성장과 건강에 관한 관심이 증대됨에 따 라 독성과 부작용이 적은 약용식물과 같은 천연물을 섭취 하고자 하는 수요가 늘고 있다(Dhama 등, 2015). 이에 따라 약용식물을 이용한 건강 기능성 식품의 시장이 커지고 있는 추세이며, 다양한 연구가 진행되고 있다(Lee, 2013).
한국의 약용소재는 전통요법에서 비롯되어 그 효능이 이미 밝혀진 경우가 많으며, 다양한 생리활성을 나타낸다 고 알려져 있다(Kim 등, 2016). 이러한 약용소재의 효능 및 생리활성에 관한 다양한 연구가 진행 중이며, 이를 활용 하여 산업화에 이용하고 있다(Kim, 2015). 하지만 건강 기능성 식품을 만들기 위해서는 효능을 나타내는 활성 성분과 관련된 연구가 우선으로 진행되는 것이 중요하며, 앞으로도 이에 관련된 연구가 진행되어야 할 필요성이 있다(Jang 등, 2016).

*Corresponding author. E-mail : kchung@knu.ac.kr, Phone : +82-53-950-5778, Fax : +82-53-950-6772

Received 18 December 2019; Revised 21 January 2020; Accepted 22 January 2020.

Copyright (c) The Korean Society of Food Preservation.

This is an Open Access article distributed under the terms of the Creative Commons Attribution Non-Commercial License (http://creativecommons.org/licenses/by-nc/4.0) which permits unrestricted non-commercial use, distribution, and reproduction in any medium, provided the original work is properly cited. 
산수유(Cornus officinalis)는 층층나무과에 속하는 낙엽 활엽소교목으로 가을에 붉은 열매를 수확하고, 종자를 제 거한 산수유 열매를 약용소재로 사용하고 있다(Park 등, 2012). 산수유의 주요 성분은 morroniside( $\mathrm{Du}$ 등, 2008), loganin(Jang 등, 2016), ursolic $\operatorname{acid}(\mathrm{Yu}$ 등, 2006)와 같은 terpenoid와 anthocyanin(Park 등, 2017), gallic acid(Wang 등, 2003) 등이 있다. 그중에서 특히 morroniside와 loganin 은 대한민국 약전에서 산수유의 지표성분으로 설정되어 있으며, 두 주요 성분 함량의 합이 $1.2 \%$ 이상으로 규정하고 있다(MFDS, 2019). 또한, 산수유 열매의 복합추출물은 식 약처에서 개별인정형 건강기능식품으로 인정되었으며, 이에 따라 산수유가 건강 기능성 소재로서 활용할 수 있는 천연소재라고 할 수 있다.

산수유 열매(Corni fructus)와 같은 약용소재로부터 활성 성분을 분리하기 위해서는 추출, 분획하는 과정을 거치거 나(Choi 등, 2011), 생리활성물질의 흡착 및 분리에 주로 사용하는 다공성 합성 흡착제를 이용한다(Choi 등, 2011). 이러한 다공성 합성 흡착제의 종류에는 chromatorex, sephadex, Diaion HP 20 등이 있으며(Noriko 등, 2007), 그 중 Diaion HP 20은 styrene과 divinyl benzene이 공중합체로 이루어져 있는 고 다공성 합성 흡착제이다(Basso 등, 2013). 산수유 열매에는 morroniside와 loganin과 같은 배당체가 존재하기 때문에 흡착제를 사용하여 분리하여야 비교적 분리가 잘 이루어진다고 알려져 있다(Liang 등, 2013).

산수유의 선행연구로는 채취시기에 따른 이화학적 특 성(Kim 등, 2019), 적정추출조건(Kang 등, 2018), 영양성분 분석(Kim 등, 2003)과 효능과 관련된 항산화성(Tural과 Koca, 2008), 항염증(Kim과 Son, 2016), 항당뇨(Kim, 2005) 등 다양한 연구가 진행되었으나, 산수유의 활성 성분에 관한 연구는 미비한 실정이다.

따라서 본 연구에서는 건강 기능성 식품 소재화를 목적 으로 산수유 열매를 $90 \%$ 에탄올로 추출하고, 추출물을 용 매분획하고 Diaion HP 20 gel chromatography로 활성 물질 을 분리하여 항산화능을 조사하고 HPLC로 분석하였다.

\section{재료 및 방법}

\section{실험재료}

산수유 열매(Corni fructus)는 경북대학교 교내에서 2018 년의 산수유 꽃의 만개일인 3 월 21 일로부터 274 일 경과된 12 월 19일에 채취하여 정선 및 수세하고 제핵하였다. 자연 건조 후 분쇄하여 시료로 사용하였다.

\section{시약 및 기기}

본 실험에서는 gallic acid, $( \pm)$-catechin, trolox, 2,2'-azinobis-3-ethylbenzothiazoline-6-sulfonic acid(ABTS), potassium chloride, 2,2-diphenyl-1-picrylhydrazyl(DPPH), 2,4,6-tris(2pyridyl)-1,3,5-triazine(TPTZ), sodium acetate, ferric chloride 는 Sigma Chemical Co.(St. Louis. Mo, USA)를 사용하였다. 추출 및 용매 분획 용매인 ethanol, $n$-hexane, ethyl acetate, $n$-butanol은 Duksan Co.(Seoul, Korea)을 사용하였다. 항산 화 활성과 항산화 함량을 분석하기 위해 UV/visible spectrometer(UV-1601, Shimadzu Co., Kyoto, Japan), microplate reader(Multiskan GO, Thermo Scientific, Waltham, MA, USA)를 사용하였다.

\section{산수유 열매의 유용성분 분리}

산수유 분말과 $90 \%$ ethanol를 $1: 20(\mathrm{w} / \mathrm{v})$ 비율로 실온에 서 3시간 추출하여 이를 여과지(Whatman No.2)에 여과하 여 산수유 조추출물을 얻어 농축하였다. 이를 $10 \%$ ethanol 에 현탁하여 $n$-hexane, ethyl acetate, $n$-butanol의 순으로 용매 분획 및 농축하여 $n$-hexane, ethyl acetate, $n$-butanol, water 획분을 얻었다.

우수한 항산화능을 나타낸 ethyl acetate 획분을 Diaion HP 20 gel을 충진한 column $(23 \times 500 \mathrm{~mm})$ 으로 Diaion HP 20 gel column chromatography를 실시하였다. Diaion HP 20 gel을 $20 \%$ ethanol로 column에 slurry packing하였고, $80 \mathrm{mg} / \mathrm{mL}$ 농도의 ethyl acetate 획분 $2 \mathrm{~mL}$ 를 gel에 흡착시켰 다. 이동상 용매로 ethanol의 농도 $(20 \%, 40 \%, 60 \%, 80 \%)$ 를 순차적으로 $2.5 \mathrm{~mL} / \mathrm{min}$ 의 유속으로 용출하였고, 각각의 획분을 얻어 감압농축 후 실험에 사용하였다.

\section{항산화 활성 측정}

$\mathrm{DPPH}$ 라디칼 소거 활성은 Blois(1958)의 방법을 변형하 여 측정하였다. 시료 $20 \mu \mathrm{L}$ 와 $200 \mu \mathrm{M} \mathrm{DPPH}$ 시액 180 $\mu \mathrm{L}$ 를 혼합하여 30 분간 암실에서 방치시킨 후 $517 \mathrm{~nm}$ 에서 분석하였다. DPPH 라디칼 소거 활성은 gallic acid를 사용 하여 검량선의 회귀식을 이용해 $\mathrm{mM} \mathrm{GAE}$ 로 나타내었다.

$\mathrm{ABTS}$ 라디칼 소거 활성은 Re 등(1999)의 방법을 이용하

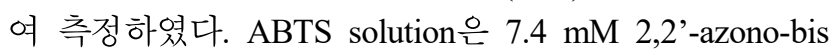
-3-ethylbenzothiazoline-6-sulfonic acid(ABTS)와 $2.45 \mathrm{mM}$ potassium persurfate를 $1: 1(\mathrm{v} / \mathrm{v})$ 로 혼합한 후 24 시간 동안 암실에서 반응시켰다. 그 후 ABTS solution을 $734 \mathrm{~nm}$ 에서 흡광도가 1.0 이 되도록 ethanol로 희석하였다. 96 well plate 에 sample $20 \mu \mathrm{L}$ 에 희석한 ABTS solution $180 \mu \mathrm{L}$ 를 넣고 5 분간 암실에서 방치한 후 $734 \mathrm{~nm}$ 에서 흡광도를 측정하였 다. Trolox를 사용하여 검량선의 회귀식을 이용해 $\mathrm{mM} \mathrm{TE}$ 로 나타내었다.

FRAP 활성은 Benzie과 Strain(1996)의 방법을 이용하여 측정하였다. Acetate buffer( $300 \mathrm{mM}, \mathrm{pH}$ 3.6), $10 \mathrm{mM}$ 2,4,6tris(2-pyridyl)-1,3,5-triazine(TPTZ) in $40 \mathrm{mM}$ hydroxy acid, $20 \mathrm{mM}$ ferric chloride solution을 $10: 1: 1$ 로 혼합하여 
cocktail solution을 제조하였다. Sample $25 \mu \mathrm{L}$ 에 cocktail solution $175 \mu \mathrm{L}$ 를 넣고 30 분간 암실에서 방치한 후, 590 $\mathrm{nm}$ 에서 흡광도를 측정하였다. Trolox를 사용하여 검량선 의 회귀식을 이용해 $\mathrm{mM} \mathrm{TE}$ 로 나타내었다.

\section{항산화 함량 측정}

총페놀성 화합물 함량은 Prussian blue assay(Graham, 1992) 방법을 변형하여 측정하였다. 96-well plate에 distilled water $75 \mu \mathrm{L}$, sample $20 \mu \mathrm{L}, 0.02 \mathrm{M}$ ferric chloride in $0.1 \mathrm{M}$ hydrogen chloride $25 \mu \mathrm{L}, 0.016 \mathrm{M}$ potassium ferricyanide $25 \mu \mathrm{L}$ 를 순차적으로 혼합하여 진탕 한 후 실온 에서 15 분간 방치하고, stabilizer(distilled water : $1 \%$ gum arabic : $85 \%$ phosphoric acid $=3: 1: 1, \mathrm{v} / \mathrm{v} / \mathrm{v}) 125 \mu \mathrm{L}$ 를 첨가한 후 $700 \mathrm{~nm}$ 에서 microplate reader(Multiskan $\mathrm{GO}$, Thermo Scientific, MA, USA)로 흡광도를 측정하였다. 총 페놀성화합물 함량은 gallic acid를 이용하여 검량선의 회 귀식을 이용해 $\mathrm{GAE} \mathrm{mg/100} \mathrm{mL}$ 로 나타내었다.

총플라보노이드 함량은 $\mathrm{Jia}$ 등(1999)의 방법을 이용하여 측정하였다. Sample $70 \mu \mathrm{L}$ 에 $50 \%$ ethanol $430 \mu \mathrm{L}, 5 \%$ sodium nitrate $50 \mu \mathrm{L}$ 를 넣고 30 분간 실온에서 반응시켰다. 그 후 $10 \%$ aluminium nitrate nonhydrate $50 \mu \mathrm{L}$ 를 넣고 혼합 한 후 5 분간 실온에서 반응시키고, $1 \mathrm{~N}$ sodium hydroxide $500 \mu \mathrm{L}$ 를 넣고 혼합하여 $510 \mathrm{~nm}$ 에서 UV-visible spectrometer(UV-1601, Shimadzu, Kyoto, Japan)를 사용하여 흡광 도를 측정하였다. 총플라보노이드 함량은 $( \pm)$-catechin을 이용하여 검량선의 회귀식을 이용해 $\mathrm{CE} \mathrm{mg} / 100 \mathrm{~mL}$ 로 나 타내었다.

총안토시아닌 함량은 Lee 등(2005)의 방법을 변형하여 측정하였으며, 조추출물, 용매 획분을 $5 \mathrm{mg} / \mathrm{mL}$ 의 농도로 실험에 사용하였다. Sample $0.5 \mathrm{~mL}$ 에 $0.025 \mathrm{M}$ potassium chloride buffer( $\mathrm{pH}$ 1.0) $0.5 \mathrm{~mL}$ 와 $0.4 \mathrm{M}$ sodium acetate buffer(pH 4.5) $0.5 \mathrm{~mL}$ 를 각각 가하여 반응시켰다. 그 후 $530 \mathrm{~nm}$ 와 $700 \mathrm{~nm}$ 에서 흡광도를 측정하였으며, 아래 식에 대입하여 계산하였다.

Total anthocyanin contents $(\mathrm{mg} / 100 \mathrm{~mL})$

$$
\begin{aligned}
& \quad=\frac{\mathrm{A} \times \mathrm{MW} \times \mathrm{D} \times 100}{\varepsilon \times 1} \\
& \mathrm{~A}=\left(\mathrm{A}_{530 \mathrm{~nm}}-\mathrm{A}_{700 \mathrm{~nm}}\right)_{\mathrm{pH} 1.0}-\left(\mathrm{A}_{530 \mathrm{~nm}}-\mathrm{A}_{700 \mathrm{~nm}}\right)_{\mathrm{pH} 4.5} \\
& \mathrm{MW}(\text { molecularweight })=449.2 \mathrm{~g} / \mathrm{mol} \\
& \mathrm{D}: \text { dilution factor } \\
& \varepsilon: \text { molar absorption coeffcient }(26,900)
\end{aligned}
$$

\section{HPLC 분석 및 UPLC-MS 분석}

$\mathrm{HPLC}$ 분석은 $\mathrm{Kim}$ 등(2009)의 방법을 이용하여 $2 \mathrm{mg} / \mathrm{mL}$
농도의 조추출물, 용매 획분을 $0.45 \mu \mathrm{m}$ syringe filter에 여과 하여 실험에 사용하였다. HPLC(1260 Infinity Quaternary LC System, Agilent Technologies, Palo Alto, CA, USA)에 Develosil ODS-HG-5 column(4.6×150 mm, $5.6 \mu \mathrm{m}$, Nomura Chemical Co., Ltd, Seto, Japan)를 사용하여 $240 \mathrm{~nm}$ 에서 분 석하였다. 분석 조건으로는 column temperature $20^{\circ} \mathrm{C}$, injection volume $10 \mu \mathrm{L}$, mobile phase는 acetonitrile : methanol $: 0.1 \%$ acetic acid in water(10:5:85, v/v/v), flow rate는 $0.5 \mathrm{~mL} / \mathrm{min}$ 로 분석하였다. 표준품은 morronisiede, loganin 을 사용하였고, 시료와 retention time을 비교하여 검량선의 회귀식을 이용해 함량 $(\mathrm{mg} / 100 \mathrm{~g})$ 을 산출하였다.

UPLC-MS는 UPLC-MS(Waters UPLC system, Waters Xevo TQ-S Smicro, Milford, USA)에 UPLC BEH ODS $(2.1 \times 50 \mathrm{~mm} \mathrm{ID}, 1.7 \mu \mathrm{m}$, Waters)를 사용하여 ESI모드에서 분석하였다. 분석조건으로 mobile phase는 acetonitrile : methanol : $0.1 \%$ acetic acid in water(10:5:85, v/v/v), injection volume $3 \mu \mathrm{L}$, flow rate는 $0.2 \mathrm{~mL} / \mathrm{min}$ 을 이용하여 positive와 negative ion mode에서 분석하였다.

\section{통계 처리}

모든 실험은 3회 반복하였으며, 그 결과를 평균과 표준 편차로 나타내었다. Statistical analysis system(SAS)(9.4, SAS Institute Inc., Cary, NC, USA)을 사용하여 Duncan의 다중검정법에 따라 유의차 검정을 실시하였다 $(\mathrm{p}<0.05)$.

\section{결과 및 고찰}

\section{산수유 열매 용매 분획물의 항산화능}

산수유 열매의 에탄올 추출물 및 용매 획분의 항산화능 은 Table 1에 나타내었다. 용매 획분의 DPPH 라디칼 소거 활성은 ethyl acetate 획분 다음으로 $n$-hexane 획분, $n$-butanol 획분, water 획분 순으로 활성이 낮아졌으며 $(\mathrm{p}<0.05)$, ABTS 소거 활성은 ethyl acetate 획분에서 가장 높은 활성 을 나타냈다 $(\mathrm{p}<0.05)$. FRAP 활성은 $0.31-18.86 \mathrm{mM} \mathrm{TE}$ 의 범위를 보였으며, ethyl acetate 획분에서 가장 높았다 $(\mathrm{p}<0.05)$. 항산화 활성은 모두 ethyl acetate 획분에서 가장 높았으며, 이는 페놀성 화합물의 영향으로 높게 나타난 것으로 사료된다. 또한, 산수유 열매의 $80 \%$ methanol 추출 물을 용매 분획하였을 때 ethyl acetate 획분에서 가장 높은 항산화 활성(DPPH 및 $\mathrm{ABTS}$ 라디칼 소거 활성)을 나타냈 다고 보고된 바 있다(Kim과 Son, 2016).

용매 획분의 총페놀성 화합물 함량은 $2.53-145.84 \mathrm{GAE}$ $\mathrm{mg} / 100 \mathrm{~mL}$ 의 범위를 나타냈으며, ethyl acetate 획분, $n$-hexane 획분, $n$-butanol 획분, water 획분 순으로 낮아졌다 $(\mathrm{p}<0.05)$. Ethyl acetate는 산수유 열매의 페놀성 화합물을 가장 효과적으로 추출할 수 있다고 알려져 있다(Stankovic 
Table 1. Antioxidant capacities of the obtained solvent fractions from Comi fructus

\begin{tabular}{|c|c|c|c|c|c|}
\hline Fraction & $90 \%$ Ethanol extract & $n$-Hexane & Ethyl acetate & $n$-Butanol & Water \\
\hline $\begin{array}{c}\text { DPPH }^{1)} \\
(\mathrm{mM} \text { GAE) }\end{array}$ & $1.64 \pm 0.09^{\mathrm{c} 2)}$ & $2.85 \pm 0.02^{\mathrm{b}}$ & $7.91 \pm 0.10^{\mathrm{a}}$ & $1.53 \pm 0.11^{\mathrm{c}}$ & $0.13 \pm 0.02^{\mathrm{d}}$ \\
\hline $\begin{array}{c}\text { ABTS } \\
(\mathrm{mM} \mathrm{TE})\end{array}$ & $1.94 \pm 0.13^{\mathrm{d}}$ & $3.94 \pm 0.11^{\mathrm{b}}$ & $13.36 \pm 0.18^{\mathrm{a}}$ & $2.43 \pm 0.10^{\mathrm{c}}$ & $0.31 \pm 0.01^{\mathrm{e}}$ \\
\hline $\begin{array}{c}\text { FRAP } \\
\text { (mM TE) }\end{array}$ & $2.82 \pm 0.07^{\mathrm{c}}$ & $3.33 \pm 0.13^{\mathrm{b}}$ & $18.86 \pm 0.32^{\mathrm{a}}$ & $3.07 \pm 0.02^{\mathrm{bc}}$ & $0.31 \pm 0.01^{\mathrm{d}}$ \\
\hline $\begin{array}{c}\mathrm{TPC} \\
(\mathrm{GAE} \mathrm{mg} / 100 \mathrm{~mL})\end{array}$ & $24.78 \pm 1.37^{\mathrm{c}}$ & $47.48 \pm 0.56^{\mathrm{b}}$ & $145.84 \pm 0.95^{\mathrm{a}}$ & $24.20 \pm 0.61^{\mathrm{c}}$ & $2.53 \pm 0.04^{\mathrm{d}}$ \\
\hline $\begin{array}{c}\mathrm{TFC} \\
(\mathrm{CE} \mathrm{mg} / 100 \mathrm{~mL})\end{array}$ & $6.83 \pm 0.25^{\mathrm{c}}$ & $85.67 \pm 0.87^{\mathrm{a}}$ & $48.67 \pm 0.12^{\mathrm{b}}$ & $4.15 \pm 0.04^{\mathrm{d}}$ & $0.48 \pm 0.00^{\mathrm{e}}$ \\
\hline $\begin{array}{c}\text { TAC } \\
(\mathrm{mg} / 100 \mathrm{~mL})\end{array}$ & $0.60 \pm 0.01^{\mathrm{c}}$ & $0.46 \pm 0.00^{\mathrm{d}}$ & $0.70 \pm 0.01^{b}$ & $0.97 \pm 0.01^{\mathrm{a}}$ & $0.01 \pm 0.00^{\mathrm{e}}$ \\
\hline
\end{tabular}

${ }^{1)} \mathrm{DPPH}, 1$ 1-diphenyl-2-picrylhydrazyl; ABTS, 2,2'-azono-bis(3-ethylbenzot hiazoline-6-sulfonic acid); FRAP, ferric ion reducing ability; TPC, total phenolic contents; TFC, total flavonoid contents; TAC, total anthocyanin contents.

2) Values represent the means $\pm \mathrm{SD}(\mathrm{n}=3)$ and different letters indicate significant differences $(\mathrm{p}<0.05)$.

등, 2014). 총플라보노이드는 $0.48-85.67 \mathrm{CE} \mathrm{mg/100} \mathrm{mL}$ 의 범위를 나타냈으며, $n$-hexane 획분에서 가장 높았다 $(\mathrm{p}<0.05)$. 총안토시아닌 함량은 $0.01-0.97 \mathrm{mg} / 100 \mathrm{~mL}$ 의 범위를 나 타냈으며, $n$-butanol에서 가장 높게 나타났다 $(\mathrm{p}<0.05)$. $n$-Hexane은 비극성 성분을 제거하기 위하여 주로 사용되 며(Han 등, 2013), n-butanol은 안토시아닌 성분을 효율적 으로 추출할 수 있다고 보고된 바 있다(Ko 등, 2017).

\section{산수유 열매 분리 분획물의 항산화능}

산수유 열매 용매 획분의 항산화능을 종합적으로 고려 하였을 때 ethyl acetate 획분의 활성이 가장 높았으며, 이
획분을 이용하여 Diaion HP 20 gel column chromatography 를 실시하였고, 각각의 획분의 항산화능을 Table 2에 나타 내었다. $40 \%$ ethanol 획분에서 $\mathrm{DPPH}$ 라디칼 소거 활성, $\mathrm{ABTS}$ 라디칼 소거 활성, FRAP 활성은 각각 0.00 - 10.22 $\mathrm{mM}$ GAE, 0.41 - $37.29 \mathrm{mM}$ TE, $0.31-27.32 \mathrm{mM}$ TE의 범위 를 나타냈다. DPPH 라디칼 소거 활성은 $80 \%$ ethanol 획분 에서 활성이 전혀 없는 것으로 나타났으며, ethyl acetate 획분이 $10.22 \mathrm{mM} \mathrm{GAE}$ 로 가장 높은 활성을 나타냈다 $(\mathrm{p}<0.05)$. ABTS 라디칼 소거 활성과 FRAP 활성은 $40 \%$ ethanol 획분에서 각각 $37.29 \mathrm{mM} \mathrm{TE}, 27.32 \mathrm{mM}$ TE로 가장 높았으며, DPPH 라디칼 소거 활성과 같은 경향을

Table 2. Antioxidant capacities of fractions from Corni fructus by Diaion HP 20 gel column chromatography

\begin{tabular}{|c|c|c|c|c|}
\hline Fraction & $20 \% \mathrm{EtOH}$ & $40 \% \mathrm{EtOH}$ & $60 \% \mathrm{EtOH}$ & $80 \% \mathrm{EtOH}$ \\
\hline $\begin{array}{c}\mathrm{DPPH}^{1)} \\
(\mathrm{mM} \text { GAE) }\end{array}$ & $0.68 \pm 0.08^{\mathrm{c} 2)}$ & $10.22 \pm 0.15^{\mathrm{a}}$ & $3.56 \pm 0.19^{\mathrm{b}}$ & $0.00 \pm 0.00^{\mathrm{d}}$ \\
\hline $\begin{array}{l}\text { ABTS } \\
(\mathrm{mM} \mathrm{TE})\end{array}$ & $4.42 \pm 0.05^{\mathrm{c}}$ & $37.29 \pm 1.00^{\mathrm{a}}$ & $18.66 \pm 0.37^{\mathrm{b}}$ & $0.41 \pm 0.00^{\mathrm{d}}$ \\
\hline $\begin{array}{c}\text { FRAP } \\
(\mathrm{mM} \mathrm{TE})\end{array}$ & $6.16 \pm 0.05^{\mathrm{c}}$ & $27.32 \pm 0.14^{\mathrm{a}}$ & $20.56 \pm 0.17^{\mathrm{b}}$ & $0.31 \pm 0.01^{\mathrm{d}}$ \\
\hline $\begin{array}{c}\mathrm{TPC} \\
(\mathrm{GAE} \mathrm{mg} / 100 \mathrm{~mL})\end{array}$ & $51.97 \pm 0.32^{\mathrm{c}}$ & $580.84 \pm 7.45^{\mathrm{a}}$ & $239.82 \pm 9.32^{\mathrm{b}}$ & $5.31 \pm 0.12^{\mathrm{d}}$ \\
\hline $\begin{array}{c}\mathrm{TFC} \\
(\mathrm{CE} \mathrm{mg} / 100 \mathrm{~mL})\end{array}$ & $16.67 \pm 0.14^{\mathrm{c}}$ & $166.24 \pm 1.31^{\mathrm{a}}$ & $54.18 \pm 0.13^{\mathrm{b}}$ & $4.22 \pm 0.10^{\mathrm{d}}$ \\
\hline $\begin{array}{c}\text { TAC } \\
(\mathrm{mg} / 100 \mathrm{~mL})\end{array}$ & $0.01 \pm 0.00^{\mathrm{b}}$ & $0.74 \pm 0.02^{\mathrm{a}}$ & $0.04 \pm 0.00^{\mathrm{b}}$ & $0.04 \pm 0.02^{\mathrm{b}}$ \\
\hline
\end{tabular}

${ }^{1)} \mathrm{DPPH}, 1$ 1-diphenyl-2-picrylhydrazyl; ABTS, 2,2'-azono-bis(3-ethylbenzot hiazoline-6-sulfonic acid); FRAP, ferric ion reducing ability; TPC, total phenolic contents; TFC, total flavonoid contents; TAC, total anthocyanin contents.

${ }^{2)}$ Values represent the means $\pm \mathrm{SD}(\mathrm{n}=3)$ and different letters indicate significant differences $(\mathrm{p}<0.05)$. 
보였다 $(\mathrm{p}<0.05)$. 복분자 딸기를 Diaion HP-20으로 활성 성 분을 분리하였을 때 $\mathrm{DPPH}$ 라디칼 소거 활성 및 $\mathrm{ABTS}$ 라디칼 소거 활성이 가장 높았다고 보고된 바 있다(Choi 등, 2011).

Diaion HP 20 gel을 이용하여 얻은 획분의 총페놀성 화합 물 함량, 총플라보노이드 함량, 총안토시아닌 함량은 각각 5.31 - 580.84 GAE mg/100 mL, 4.22 - 166.24 CE mg/100 $\mathrm{mL}, 0.01-0.74 \mathrm{mg} / 100 \mathrm{~mL}$ 의 범위를 나타냈다. 총페놀성 화합물 함량은 $40 \%$ ethanol 획분에서 가장 높았으며, $60 \%$, $20 \%, 80 \%$ ethanol 획분 순으로 낮아졌다 $(\mathrm{p}<0.05)$. 또한, ethyl acetate 획분보다 약 3.98 배 증가하여 가장 높은 함량 을 나타냈다 $(\mathrm{p}<0.05)$. 총플라보노이드 함량 및 총안토시아 닌 함량도 $40 \%$ ethanol 획분에서 가장 높았다 $(\mathrm{p}<0.05)$.

\section{산수유 열매 분리 분획물의 활성 성분 분석}

활성 성분을 HPLC로 분석하고, 표준물질을 농도별로 함량을 계산해 검량선의 회귀식을 얻었다. Retention time 은 10.16 분에 morroniside, 20.95 분에 loganin이 검출되었으 며(Fig. 1), 활성 성분의 함량은 Table 3에 나타내었다. 산수 유의 에탄올 추출물에서 morroniside와 loganin이 각각 $136.36 \mu \mathrm{g} / \mathrm{mL}, 53.29 \mu \mathrm{g} / \mathrm{mL}$ 로 나타났다. 항산화능이 가장 높은 ethyl acetate 획분에서는 morroniside와 loganin이 각각 $36.02 \mu \mathrm{g} / \mathrm{mL}, 149.72 \mu \mathrm{g} / \mathrm{mL}$ 로 나타났다 $(\mathrm{p}<0.05)$. 용매분획 을 하였을 때, morrniside는 $n$-butanol 획분, loganin은 ethyl acetate 획분에서 증가하는 것으로 분석되었다.

$20 \%$ ethanol 획분에서는 morroniside와 loganin이 각각 $20.07 \mu \mathrm{g} / \mathrm{mL}, 16.66 \mu \mathrm{g} / \mathrm{mL}, 40 \%$ ethanol 획분에서는 80.05 $\mu \mathrm{g} / \mathrm{mL}, 151.74 \mu \mathrm{g} / \mathrm{mL}$ 로 나타났다. $40 \%$ ethanol 획분에서 morroniside와 loganin의 함량이 가장 높았으며 $(\mathrm{p}<0.05)$, 가 장 우수한 항산화능을 나타낸 결과와도 같은 경향을 나타 내었다. 산수유 열매의 morroniside나 loganin과 같은 iridoid glycoside 물질은 Diaion HP 20을 이용할 때 분리가 잘 된다고 보고된 바 있다(Wang 등, 2018). 본 결과에서도 ew $40 \%$ ethanol 획분에서 loganin이 가장 높은 함량을 나타 내었으며, 산수유 열매의 항산화능을 나타내는 주요 활성
(A)

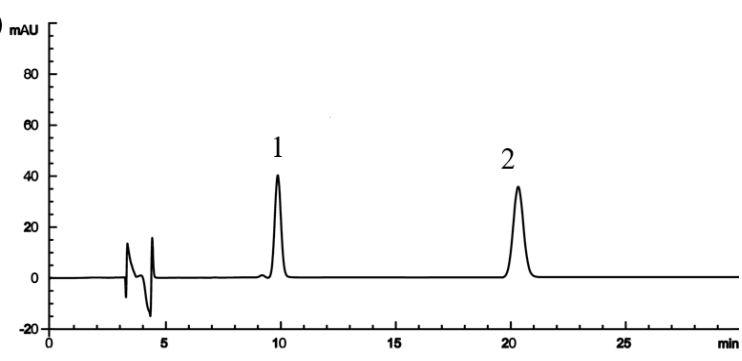

(B)

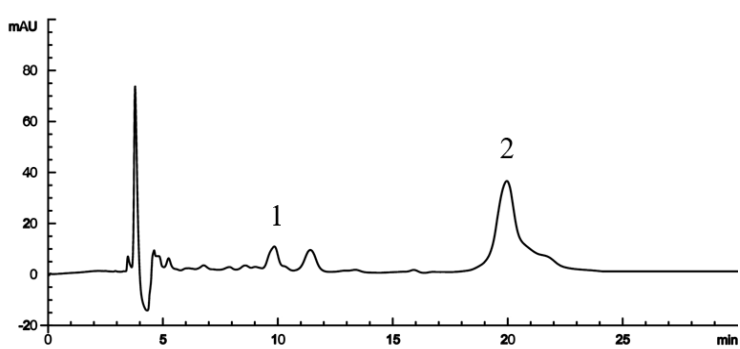

(C)

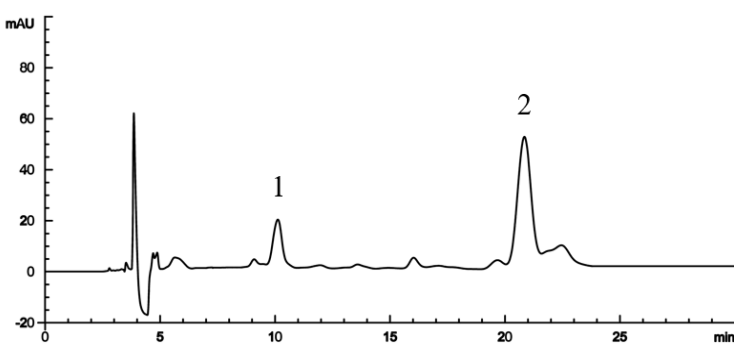

Fig. 1. HPLC chromatogram of standard compounds (A), ethyl acetate fraction (B), and $40 \%$ ethanol fraction by Diaion HP 20 gel column chromatography (C).

1, morroniside; 2, loganin.

성분으로 사료된다.

$40 \%$ ethanol 획분의 HPLC로 분석한 산수유의 활성 성분 인 morroniside 및 loganin을 UPLC-MS로 표준품과 비교하 여 분자량을 확인하였다(Fig. 2). Negative 조건에서 morronisde와 loganin 각각 405[M-H]-와 451[M+COOHH]-, $389[\mathrm{M}-\mathrm{H}]-$ 와 435[M+COOH-H]-로 나타났으며, 이는 각각 분자량의 parent ion이라고 보고된 바 있다(Cao 등, 2011).

Table 3. Contents of morroniside and loganin of the obtained solvent fractions from Corni fructus

\begin{tabular}{|c|c|c|c|c|c|c|c|c|c|}
\hline \multirow{2}{*}{ Fraction } & \multirow{2}{*}{$\begin{array}{l}90 \% \text { Ethanol } \\
\text { extract }\end{array}$} & \multirow{2}{*}{ n-Hexane } & \multirow{2}{*}{$\begin{array}{l}\text { Ethyl } \\
\text { acetate }\end{array}$} & \multirow{2}{*}{$n$-Butanol } & \multirow{2}{*}{ Water } & \multicolumn{4}{|c|}{ Diaion HP 20 gel column chromatography } \\
\hline & & & & & & $20 \% \mathrm{EtOH}$ & $40 \% \mathrm{EtOH}$ & $60 \% \mathrm{EtOH}$ & $80 \% \mathrm{EtOH}$ \\
\hline Morroniside & $136.36 \pm 2.97^{\mathrm{bl})}$ & -2) & $36.02 \pm 0.7^{\mathrm{c}}$ & $295.49 \pm 9.14^{\mathrm{a}}$ & - & $20.07 \pm 1.04^{\mathrm{b}}$ & $80.05 \pm 3.18^{\mathrm{a}}$ & - & - \\
\hline Loganin & $53.29 \pm 2.04^{\mathrm{b}}$ & - & $149.72 \pm 5.37^{\mathrm{c}}$ & $118.49 \pm 6.08^{\mathrm{a}}$ & - & $16.66 \pm 0.58^{\mathrm{b}}$ & $151.74 \pm 8.67^{\mathrm{a}}$ & - & - \\
\hline Total & $189.65 \pm 5.01^{\mathrm{b}}$ & - & $185.74 \pm 6.06^{\mathrm{c}}$ & $413.98 \pm 15.08^{\mathrm{a}}$ & - & $36.73 \pm 1.55^{\mathrm{b}}$ & $231.79 \pm 11.51^{\mathrm{a}}$ & - & - \\
\hline
\end{tabular}

${ }^{1)}$ Values represent the means $\pm \mathrm{SD}(\mathrm{n}=3)$ and different letters indicate significant differences $(\mathrm{p}<0.05)$.

${ }^{2)}$ Not detected. 

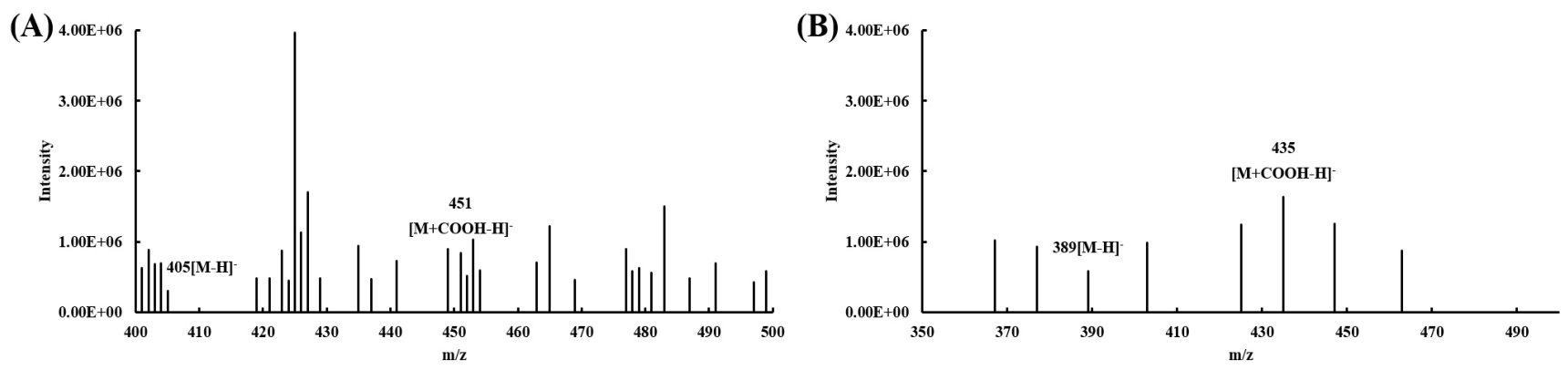

Fig. 2. UPLC-MS spectrums of morroniside (A), and loganin (B) from 40\% ethanol fraction by Diaion HP 20 gel column chromatography.

\section{요 약}

산수유 열매의 건강 기능성 소재화를 위하여 산수유 열매의 $90 \%$ 에탄올 추출물을 용매 분획하여 항산화능을 측정하고, 이에 기여하는 활성 성분(morroniside, loganin)을 Diaion HP 20 gel로 분리하였다. 산수유 열매의 추출물 및 획분의 항산화능 측정 결과, 이 중 ethyl acetate 획분에서 항산화능이 가장 높게 나타났다 $(\mathrm{p}<0.05)$. 이를 이용하여 Diaion HP 20 gel column chromatography를 실시하였으며, $20 \%, 40 \%, 60 \%, 80 \%$ ethanol 획분을 얻었다. $40 \%$ Ethanol 획분에서 항산화 활성인 $\mathrm{DPPH}$ 라디칼 소거 활성(10.22 $\mathrm{mM} \mathrm{GAE}), \mathrm{ABTS}$ 라디칼 소거 활성(37.29 mM TE), FRAP 활성 $(27.32 \mathrm{mM}$ TE)으로 가장 높게 나타났다 $(\mathrm{p}<0.05)$. 항산 화 성분 함량인 총페놀성화합물 함량 $(580.84 \mathrm{GAE} \mathrm{mg/100}$ $\mathrm{mL})$, 총플라보노이드 함량 $(166.24 \mathrm{CE} \mathrm{mg/100} \mathrm{mL)} \mathrm{및} \mathrm{총안}$ 토시아닌 함량 $(0.74 \mathrm{mg} / 100 \mathrm{~mL})$ 은 항산화 활성의 결과와 같은 경향을 나타냈다. Ethyl acetate 획분을 Diaion HP 20 gel을 이용하여 분획하였을 때 $40 \%$ ethanol 획분에서 항산 화능이 가장 높게 나타났으며, 물질 분리로 인하여 항산화 능이 증가한 결과를 보였다. 항산화능이 높게 나타난 ethyl acetate 획분의 활성 성분을 HPLC로 분석한 결과 morroniside 와 loganin의 함량은 각각 $36.02 \mu \mathrm{g} / \mathrm{mL}$ 및 $149.72 \mu \mathrm{g} / \mathrm{mL}$ 로 가장 높았다 $(\mathrm{p}<0.05)$. 또한, Diaion HP $20 \mathrm{gel}$ 을 이용하여 얻은 획분에서 morroniside와 loganin성분을 HPLC로 분석 한 결과, $40 \%$ ethanol 획분이 가장 높았다 $(\mathrm{p}<0.05)$. UPLC$\mathrm{MS}$ 를 이용하여 $40 \%$ ethanol 획분의 활성 성분을 분석한 결과, morroniside 및 loganin의 parent ion이 각각 405[M-H]와 $451[\mathrm{M}+\mathrm{COOH}-\mathrm{H}]-, 389[\mathrm{M}-\mathrm{H}]-$ 와 $435[\mathrm{M}+\mathrm{COOH}-\mathrm{H}]$-로 나타났다. 따라서, 산수유 열매의 $40 \%$ ethanol 획분의 항산 화능에 loganin이 기여하는 것으로 사료된다.

\section{Conflict of interests}

The authors declare no potential conflict of interest.
Su-Hui Kim https://orcid.org/0000-0001-7692-4005

Shin-Kyo Chung https://orcid.org/0000-0002-0905-3008

\section{References}

Basso A, Froment L, Hesseler M, Serban S. New highly robust divinyl benzene/acrylate polymer for immobilization of lipase CALB. Eur J Lipid Sci Technol, 115, 468-472 (2013)

Benzie IF, Strain JJ. The ferric reducing ability of plasma (FRAP) as a measure of "antioxidant power": The FRAP assay. Anal Biochem, 239, 70-76 (1996)

Blois MS. Antioxidant determinations by the use of a stable free radical. Nature, 181, 1199-1200 (1958)

Cao G, Cai H, Zhang Y, Cong X, Zhang C, Cai B. Identification of metabolites of crude and processed Fructus Corni in rats by microdialysis sampling coupled with electrospray ionization linear quadrupole ion trap mass spectrometry. J Pharm Biomed Anal, 56, 118-125 (2011)

Choi SJ, Lee YS, Kim JK, Chung CK, Kang IJ, Lim SS. Antioxidant activity of ripe fruit components of Rubus coreanus: Extraction using porous polymer resins. Korean J Food Sci Technol, 43, 149-155 (2011)

Dhama K, Latheef SK, Mani S, Samad HA, Karthik K, Tiwari R, Khan RU, Alagawany M, Farag MR, Alam GM, Laudadio V, Tufarelli V. Multiple beneficial applications and modes of action of herbs in poultry health and production-A review. Int J Pharmacol, 11, 152-176 (2015)

Du W, Cai H, Wang M, Ding X, Yang H, Cai B. Simultaneous determination of six active components in crude and processed Fructus Corni by high performance liquid 
chromatography. J Pharm Biomed Anal, 48, 194-197 (2008)

Graham HD. Stabilization of the prussian blue color in the determination of polyphenols. J Agric Food Chem, 40, 801-805 (1992)

Han SB, Kwon SS, Kong BJ, Kim KJ, Park SN. Antioxidative effect and tyrosinase inhibitory activity of the unripened fruit extract of Rubus coreanus Miquel. J Soc Cosmet Scientists Korea, 39, 295-302 (2013)

Im DY, Lee KI. Antioxidative activity and active compound analysis of the extract and fractions of Corni Fructus. Korean J Pharmacogn, 48, 208-212 (2017)

Jang DE, Lee SH, Hwang IG, Song J, Hwang KA. Method validation for the analysis of loganin content in Cornus officinalis depends on cultivation regions. Food Eng Prog, 20, 152-157 (2016)

Jia Z, Tang M, Wu J. The determination of flavonoid contents in mulberry and their scavenging effects on superoxide radicals. Food Chem, 64, 555-559 (1999)

Kang CJ, Seong GU, Chung SK. Optimization of extraction conditions of Corni Fructus for functional materialization. Korean J Food Preserv, 25, 676-681 (2018)

Kim HR, Park GN, Jung BK, Shin YS, Chang KS. Physiological activities using root and stem extracts of cymbidium. J of Korean Oil Chemists Soc, 33, 848-854 (2016)

Kim HS, Kim KR, Hong CO, Go WR, Jeong SH, Yoo JH, Cho NJ, Hong JH, Kim WI. Monitoring of $\mathrm{Cd}, \mathrm{Hg}, \mathrm{Pb}$, and As and risk assessment for commercial medicinal plants. Korean J Environ Agric, 34, 282-287 (2015)

Kim OK. Antidiabetic and antioxidative effects of Corni fructus in streptozotocin-induced diabetic rats. J of Korean Oil chemist Soc, 22, 157-167 (2005)

Kim SH, Kang CJ, Seong GU, Chung SK. Physicochemical quality characteristics of Corni Fructus depending on the picking periods. Korean J Food Preserv, 26, 740-744 (2019)

Kim SH, Lee MK, Ahn MJ, Lee KY, Kim YC, Sung SH. Efficient method for extraction and simultaneous determination of active constituents in Cornus officinalis by reflux extraction and high performance liquid chromatography with diode array detection. J Liq Chromatogr Relat Technol, 32, 822-832 (2009)

Kim YD, Kim HK, Kim KJ. Analysis of nutritional components of Cornus officinalis. J Korean Soc Food Sci Nutr, 32, 785-789 (2003)
Kim YJ, Son DY. Antioxidant activity and suppression of pro-inflammatory mediator of Corni fructus extracts in activated RAW 264.7 macrophage. Korean J Food Preserv, 23, 876-882 (2016)

Ko GA, Koh SY, Ryu JY, Cho SK. Comparison of proximate compositions, antioxidant, and antiproliferative activities between blueberry and Sageretia thea (Osbeck) MC Johnst fruit produced in Jeju Island. J Appl Biol Chem, 60, 161-171 (2017)

Lee JM, Durst RW, Wrolstad RE. Determination of total monomeric anthocyanin pigment content of fruit juices, beverages, natural colorants, and wines by the $\mathrm{pH}$ differential method: Collaborative study. J AOAC Int, 88, 1269-1278 (2005)

Lee NY. Antioxidant effect and tyrosinase inhibition activity of seaweeds ethanol extracts. J Korean Soc Food Sci Nutr, 42, 1893-1898 (2013)

Liang J, He J, Zhu S, Zhao W, Zhang Y, Ito Y, Sun W. Preparation of main iridoid glycosides in Fructus Corni by macroporous resin column chromatography and countercurrent chromatography. J Liq Chromatogr Relat Technol, 36, 983-999 (2013)

MFDS. The Korean Pharmacopoeia. 11th ed, Korea Food \& Drug Administration, Seoul, Korea, p 1819-1820 (2019)

Noriko Y, Kang KS, Yosuke M, Takashi T, Takako Y. Identification of antidiabetic effect of iridoid glycosides and low molecular weight polyphenol fractions of Corni Fructus, a constituent of hachimi-jio-gan, in streptozotocininduced diabetic rats. Biol Pharm Bull, 30, 1289-1296 (2007)

Park EB, Kim HS, Shin SY, Ji IA, Kim JH, Kim SG, Yoo BH, Kim BW, Kwak IS, Kim MM, Chung KT. Antioxidative activity of Cornus officianalis extracts obtained by four different extraction techniques. J Life Sci, 22, 1507-1514 (2012)

Park SJ, Jeong JS, Jeong JH, Park NJ, Son BG. Morroniside, loganin, and cornin contents and physicochemical properties of commercial Sansuyu (Corni fructus) retort drink. J Korean Soc Food Sci Nutr, 46, 1018-1025 (2017)

Re R, Pellegrini N, Proteggente A, Pannala A, Yang M, Rice-Evans C. Antioxidant activity applying an improved ABTS radical cation decolorization assay. Free Radical Biol Med, 26, 1231-1237 (1999)

Stankovic MS, Zia-Ul-Haq M, Bojovic BM, Topuzovic MD. Total phenolics, flavonoid content and antioxidant power 
of leaf, flower and fruits from cornelian cherry (Cornus mas L.). Bulg J Agric Sci, 20, 358-363 (2014)

Tural S, Koca I. Physico-chemical and antioxidant properties of cornelian cherry fruits (Cornus mas L.) grown in Turkey. Sci Hortic, 116, 362-366 (2008)

Wang SF, Chen XG, Hu ZD, Ju Y. Analysis of three effective components in Fructus corni and its preparations by micellar electrokinetic capillary chromatography. Biomed Chromatogr, 17, 306-311 (2003)
Wang X, Liu CH, Li JJ, Zhang B, Ji LL, Shang XY. Iridoid glycosides from the fruits of Cornus officinalis. J Asian Nat Prod Res, 20, 934-942 (2018)

Yu HH, Seo SJ, Hur JM, Park RK, So HS, Jeon BH, You YO. Protective effect of ursolic acid from Corni fructus on the hydrogen peroxide-induced damage of HEI-OC1 auditory cells. Korean J Oriental Physiology Pathology, 20, 1524-1529 (2006) 